\title{
(息)
}

Citation:

Bonilla-Priego, MJ and Font, $X$ and Pacheco-Olivares, MDR (2014) Corporate sustainability reporting index and baseline data for the cruise industry. Tourism Management, 44. 149 - 160. ISSN 0261-5177 DOI: https://doi.org/10.1016/j.tourman.2014.03.004

Link to Leeds Beckett Repository record:

https://eprints.leedsbeckett.ac.uk/id/eprint/130/

Document Version:

Article (Submitted Version)

This is the author's pre-print and may vary from the final published version

The aim of the Leeds Beckett Repository is to provide open access to our research, as required by funder policies and permitted by publishers and copyright law.

The Leeds Beckett repository holds a wide range of publications, each of which has been checked for copyright and the relevant embargo period has been applied by the Research Services team.

We operate on a standard take-down policy. If you are the author or publisher of an output and you would like it removed from the repository, please contact us and we will investigate on a case-by-case basis.

Each thesis in the repository has been cleared where necessary by the author for third party copyright. If you would like a thesis to be removed from the repository or believe there is an issue with copyright, please contact us on openaccess@leedsbeckett.ac.uk and we will investigate on a case-by-case basis. 


\section{Corporate sustainability reporting index and baseline data for the cruise industry}

Sustainability policies and corporate reports demonstrate the impacts cruise companies acknowledge as their responsibility, and the actions put in place to address them. This paper develops a corporate social responsibility index based on the Global Reporting Initiative, with industry specific additions including labor and human rights, health and safety, and environmental and economic aspects. Companies disclose more management than performance data, which is typical of early stages of development. Companies disclosing less information focus on soft indicators which are easy to mimic and demonstrate posturing. Items disclosed tend to be marginal to the core of the business, have a positive economic impact or pre-empt sector regulation. Reports echo the voice of the corporations and not the demands of stakeholders. Institutional isomorphism has not influenced a homogenization in reporting, with only the largest firms reporting at this stage.

Keywords: social, environmental, responsibility, legitimization, stakeholder, Global Reporting Initiative

\section{Introduction}

There is a well-established but growing demand on corporations to perform not only financially but to be good citizens as "the social responsibility of business encompasses the economic, legal, ethical and discretionary expectations that society has of organizations at a given point in time"(Carroll, 1979:500). As society's stakeholders become more concerned with staff welfare, the impact on the environment and local communities, they will put pressure on the most visible corporations to address the issues. Taking responsibility is therefore the process of accepting the expectations placed by society (Goodwin, 2011), and accountability is the duty of providing an account for meeting those expectations (Gray, Colin, Owen, Evans, \& Zadek, 1997). While accounting of financial responsibilities is well established (but not without its loop holes), the requirements for reporting "additional" but real responsibilities develop according to society's expectations. As either issues (e.g. carbon) or sectors (e.g. extractive industries) become recognized for their potential harm, industry leaders develop mechanisms to respond.

Cruising is increasingly being called to scrutiny. The significant growth in the last two decades has been explained by the attractiveness of the affordable fares, product quality and both product and destination diversification (ECC, 2012; ICCA, 2012). Yet larger vessels, corporate visibility and negative media coverage of environmental impacts, limited positive economic impact on destinations, poor labor conditions and the 2012 Costa Concordia accident have raised industry awareness of the need to legitimize how the sector is taking responsibility for society and the environment. This has resulted in increased corporate social reporting and industry wide promotional efforts.

Corporate Social Responsibility (CSR) practices are intended to have many positive effects such as improving social and environmental performance and constituting an instrument to manage stakeholder relations (Kaptein and Wempe, 1998). However, 
theyhave not always satisfied this intention as CSR reports do not always represent a genuine attempt to account for negative as well as positive aspects of all material impacts (Adams, 2004). There are different practices that undermine the benefits of transparency and credibility, and a wide range of theories about why and how companies report.

Voluntary disclosure theory claims that firms are willing to disclose good news to differentiate themselves following a resource-based view of the firm (Barney, 1991; Branco \& Rodrigues, 2006; Healy \& Palepu, 2001), often tested by suggesting a positive relation between financial and sustainability performance (Campbell, 2007; Garay \& Font, 2012). In contrast, stakeholder and legitimacy theory see disclosure as a response to social and political pressures and is therefore reactive, predicting a negative relation between environmental performance and voluntary environmental disclosure (Adams, Hill, \& Roberts, 1998; Deegan, 2002; Hooghiemstra, 2000). Since legitimacy relies on meeting social systems' expectations, this approach lends itself well to explain Carroll's definition in the first paragraph, although there are those claiming that market-driven stakeholder accountability will produce reports that are in the organization's best interests (Gray, et al., 1997).

Reputation risk management and impression management are commonly the intended purpose behind corporate social reporting (Bebbington, Larrinaga, \& Moneva, 2008; Hooghiemstra, 2000). Evidence suggests that environmental managers determine the contents of their CSR reports based on their understanding of the relative importance of different stakeholders (Cormier, Gordon, \& Magnan, 2004). Firms prefer to disclose major environmental events when they feel threatened by stakeholders, and disclose by defending what has been done about it retrospectively as a means of maintaining or restoring legitimacy (Elijido-Ten, Kloot, \& Clarkson, 2010). Deegan (2002) summarizes some of the possible reasons for disclosure as economic rationality, acceptance of accountability responsibilities, and meeting requirements of or preventing pressure from various stakeholders including government, lenders, buyers, suppliers, industry associations, amongst others. Companies disclose more according to their size, ownership- publicly traded or government owned-, low levels of debt, age of fixed assets, environmental footprint and risk (Cormier, Magnan, \& Van Velthoven, 2005; Eng \& Mak, 2003; Jose \& Lee, 2007).

Academics call for fine tuned metrics to capture sustainability disclosure so it better reflects performance ( Jose \& Lee, 2007; Morhardt, 2010), since CSR reports do not always demonstrate accountability. Companies often use CSR reporting as a public relations exercise to manage impressions and improve their reputation (ODwyer, $\underline{2003}$ ), but also to provide internal sustainability accounting data for management purposes. The breadth of this data will depend on the corporate priorities, often focusing on environmental aspects that lead to operational savings, or in the more advanced cases ranging the triple bottom line of environment, society and economy. Stakeholders need meaningful and comparable information which comprises externally verified data and methodologies which can utilise that data. Triple bottom line reporting requires an index for measuring and reporting corporate performance. However, in 
cruising we are still at the stage of cataloguing and categorizing impacts to form a sector specific list of indicators.

The contribution of this paper is two-fold. First, it proposes an index to measure and report corporate performance by adapting generic reporting systems to the cruise industry characteristics. Second, it conducts primary research on the level of responsibility accepted by the cruise industry by analyzing their CSR reports.

This index results from adapting reporting systems such as the Global Reporting Initiative (GRI), the Carbon Disclosure Program and other international initiatives together with literature specific to the cruise industry to develop a sector specific instrument. These metrics encompass both the setting up of management systems and the development of specific performance indicators. This includes assessing management indicators such as having departments, management positions, committees and stakeholder involvement (Adams, 2008). It also requires independent verification of the credibility of company reports (Laufer, 2003). GRI includes both items and validates the level of disclosure achieved, but fails to require external audits. While these are important elements of the literature review, they apply to all industries and for brevity reasons cannot be described in detail here.

The index will require industry adaptation. For example, as a result of the registration policy, a ship is considered the territory of the country in which it is registered and this is why many vessels are registered in countries without stringent laws or the capacity to monitor safety and working conditions and investigate incidents. When the ship is in international waters, it comes under the jurisdiction of the flag registry plus international laws (covering only some environmental standards, and not socio-economic). Ship Safety Certificates are given out by private classification societies and the worse the conditions of the ship, the more likely they are to choose a less demanding society (Doherty, 2012, see also tables 1 and 2). Having clarified this industry specific issue, the remainder of the literature review outlines cruise industry impacts and efforts to respond to them, subsequently used in the methodology.

The literature suggests that corporate social reports are valid instruments to understand how companies acknowledge certain responsibilities in relation to given stakeholder pressures (Kaptein, 2007; Krippendroff, 1980). Many of these studies focus on analyzing the selection of issues and the type of information provided. This selection would help to uncover the issue of the inclusivity of stakeholders in the reporting process and the use of the social report as a legitimization tool (Adams, 2004). It is worth noting that in keeping with similar exploratory studies, this study measures CSR reporting (what impacts companies accept and how they deal with them), and not CSR performance (to which extent their actions actually deal appropriately with the impacts). We analyze CSR reporting using a typology format, developing an index and then attributing scores to whether companies report on taking action on each indicator, which allows for numerical comparison and categorization (Kolk \& Mauser, 2002; Morhardt, 2010). Focusing on a single industry allows us to provide some insights on the corporate characteristics conditioning social reporting worthy of further research. 
We provide a justification for the index in the remainder of the literature review, before testing it through a content analysis of the publicly available data from the 29 out of a population of 80 cruise companies that report CSR practices. Some 11 of these publish corporate social responsibility reports, and 18 make some statements on their website. The content of the reports are classified according to the type and format of data disclosed, according to environmental and socio-economic, hard and soft, management and performance variables. These are then compared against company characteristics- size, reporting experience and whether they produce CSR reports or disclose on their website. The patterns are then analyzed in the Discussion section against the literature outlined above on the motivations for CSR disclosure- this shows the industry has not reached a mimetic behavior, but disclosure depends on company size, practices disclosed follow beyond compliance theory reputation risk management, with little commitment to change the core of the business. The consequences for the maturity of CSR reporting in the cruise industry are then summarized in the conclusions.

\section{Environmental impacts}

Environmental impacts are most commonly described by international organizations such as the IMO (International Maritime Organization) through MARPOL (International Convention for the prevention of Pollution from Ships), first adopted in 1973 and continuously updated through the years. They are also recognized by the European Union (COM, 2007). Impacts will be reviewed following the GRI format: materials, water, biodiversity, emissions/effluents/waste, and products and services.

The first two environmental aspects listed under the GRI are the consumption of materials and water. Large cruise ships are luxury floating cities with more comfort than a population of that size requires: resources consumed approach 1.5 times normal consumption patterns (Véronneau \& Roy, 2009), and overconsumption creates pressure in areas where there is a shortage of fresh water. In either aspect there is no literature specific to the cruise industry. Sustainable supply chain management approaches would be needed to both reduce the consumption and wastage, as well as to consider the origin of the materials used and the impact of overusing water (Font, Tapper, Schwartz, \& Kornilaki, 2008).

The third aspect is biodiversity, from at least two operational areas in addition to the impacts resulting from constructing the ships. The impact on biodiversity from consumption onboard the ship would be similar to that of hotels (IUCN, 2008), for example the type of food and other produce used. The impact from discharges is specifically of concern, as cruises usually operate in highly valued coastal water and marine ecosystems. Two examples are covered here. First, many ships use hull coatings, also called anti-fouling systems, as a surface treatment to control or prevent attachment of unwanted organisms that would result in increased fuel requirements and spread invasive species around the world. However, some anti-fouling coatings contain hazardous chemicals which can be harmful to marine organisms. There are biocides with a low risk biological accumulation, and some other possible solutions (EMEC, 2010). 
A more widespread biodiversity impact occurs from carrying ballast water to keep cruises stable in the water. The IMO noted the negative impact of non-indigenous organisms transported in the ballast water back in 1970. In 2004 the IMO adopted the International Convention for the Control and Management on Ship's Ballast Water and Sediments to protect waters from non-indigenous aquatic organisms and pathogens that can be harmful to ecosystems. Although this convention did not enter into force as it was only signed by 33 states by January 2012 (IMO, 2011), the harm from ballast water is well recognized (Gollasch, Lenz, Dammer, \& Andres, 2000; Williams, Griffiths, Van der Wal, \& Kelly, 1988). For example U.S. regulation sets standards for discharges within three miles of the shoreline and California requires ships to treat ballast water before dumping it in ports or coastal waters (Klein, 2011) through various technologies (EMEC, 2010).

The fourth, and most detailed GRI aspect is emissions, effluents and waste. A cruise vessel generates and disposes of millions of gallons of liquid waste in the form of gray and black water which not only threatens shellfish beds, coral reefs and other marine ecosystems, but also human health (EPA, 2004). Gray water is the wastewater from sinks, showers or laundry and is not covered by international regulations; while black water is the waste from cruise ships toilets and medical facilities- and is regulated. Cruise ships that comply with legislation and are under international regulation (Annex IV MARPOL), may still discharge comminuted and disinfected sewage using a system approved by its flag administration at a distance of more than three nautical miles from shore. A ship may discharge untreated sewage at a distance of more than twelve nautical miles and when the vessel is traveling at a speed of no less than four knots. Untreated black water is discharged under the assumption that oceans can dilute any pollution. Two treatment systems are used, the traditional type II marine sanitation device and the most advanced water treatment systems, which still generate important impacts (Klein, 2011). Therefore, to be able to claim environmental responsibility, companies should use an advanced system consistently, not just depending on the jurisdiction.

In tonnage terms, the most important pollutant resulting from shipping operations is oil (Gard, 2011). MARPOL allows discharges (within twelve miles from shore) of bilge water through an oily water separator which generates an effluent with an oil content that does not exceed 15 parts per million. It also requires all vessels to maintain a sludge tank to store oil wastes, which can be incinerated or pumped ashore since it is considered a hazardous waste.

The emissions caused by a cruise ship depend on many variables, for example the size and age of the vessels, which determine the power needed and the type of fuel used. Most cruise ships use residual oil, also known as heavy fuel oil, a thick, highly sulfurous fuel (EC, 2009). Additionally, carbon dioxide is the most important greenhouse gas emitted by ships, both in terms of quantity and of global warming potential. However, emissions are also created by the burning of waste onboard. There are different ship-based facilities that can be installed to reduce NOx, SOx and particulate matter. However, the best way to reduce impacts from emissions is to use less combustible or replace them with less harmful power sources such as natural gas, solar panels or wind-powered systems (ECC, 2011). In fact, MARPOL Annex VI 
regulations include caps on the sulfur content of fuel oil to control SOx and PM emissions. This Annex was reviewed in the last few years and a progressive reduction in emissions of SOx, NOx and particulate matter was introduced. Emissions Control Areas where the emissions limits are further restricted were established in the Baltic and North Seas and North America.

Most waste treated on board is pulped, ground or incinerated and the ash is discharged overboard. Although legal under certain circumstances, the disposal of waste overboard increases biological and chemical oxygen demand, total organic carbon, and turbidity and nutrient levels, and also diminishes water and sediment quality among many others impacts (EPA, 2008). Incinerators on board also increase air emissions and other impacts when ash is dumped into the sea, except ashes from plastic products which may contain toxic or heavy metal residues which cannot be dumped. Solid waste management practices should reduce, recycle and process before discharging onshore. Because of the pressure on changeover day, recycling often occurs at intermediate ports (Véronneau \& Roy, 2009).

\section{Socio-economic impacts}

While there are environmental impacts specific to the cruise industry, socio-economic impacts are not dissimilar to those caused by large scale resorts. They differ however in their concentration in time and space, their location in high pressure areas, and the compliance with regulations of the country where the ship is registered.

Following the GRI structure, the index includes labor conditions such as employment, labor management relations, occupational health and safety, training and education, diversity and equal opportunity. Additional indicators on the accommodation and working conditions of staff and working hours were added based on the literature. Work conditions differ considerably from land based staff, due to the temporary nature of contracts, working in isolation during long periods of time, and unclear application of legislation unfavourable to the workers due in part to the use of flags of convenience (Bauer, 2007; Dimitrova \& Blanpain, 2010; Terry, 2009). Intermediary and recruitment agencies in developing countries add charges for medical examinations, visas, transport and administration and often put workers into a level of debt that cannot be repaid and comparable to forced labor (Ross A Klein, 2003).

The second social issue is human rights, including investment and procurement practices, non-discrimination, freedom of association and collective bargaining, child labor, forced and compulsory labor, security practices, and indigenous rights. Indicators generally revolve around incident reporting. There is evidence of frequent violation of rights for disadvantaged groups with tasks allocated and salaries paid according to nationality and cultural background, not capability or performance (Brida \& Zapata, 2010; Terry, 2009). Labor rights in general and unionisation in particular are complex since the laws of the vessel's registration apply on board- many workers begin work in debt to secure on board placements, and working hours and living conditions are below those expected on shore (Lillie, 2005). Both of these labor issues face increased legislation since 2013 with the introduction of the Maritime Labor Convention (Piniella, Silos, \& Bernal, 2013). 
The third social issue to be reviewed is the impact on society, including community, corruption and compliance. Besides the generic GRI indicators, it is worth mentioning cruises change the character of harbor areas in destinations, often making them unattractive to local citizens (Seidl, Guiliano, \& Pratt, 2007) and land-based tourists alike (Klein, 2011). This is especially acute in small destinations where the ratio to cruise passenger per resident is high (Brida \& Zapata, 2010) and is causing a "crowding-out trap" of the stay-over tourism (Bresson \& Logossah, 2011).

The final issue is product responsibility including health and safety, while product and service labelling, marketing communications, customer privacy and compliance will be reviewed following generic GRI indicators. Health and safety of customers and staff is an aspect of corporate responsibility. The ShipSan Project Study results revealed a diversity of approaches and practices in the conduct of ship inspections, differences in the competencies of inspectors and the legislation applied during inspections, and a lack of communication and training among many European Union member states (Hadjichristodoulou, et al., 2011). Recognizing that there is a need for standards, a manual was published with guidelines and best practices (EC, 2011). The 2012 Costa Concordia disaster has reminded us that ships may not be able to help all passengers abandon the ship within 30 minutes. The International Convention for the Safety of Life at Sea (SOLAS) must be updated to suit the modern cruiseline industry since SOLAS was first published when ships accommodated no more than 2,000 passengers (Klein, 2012).

The American Medical Association called for awareness on the limited medical services available aboard ships (Klein, 2012). "Keeping on top of health" appears as an industry association target (CLIA, 2012). Medical services depend on ship size, duration, destination of the voyage and the number of passengers and crew. Directive 92/29/EEC on the minimum safety and health requirements for improved medical treatment on board vessels establish some requirements on sanitary personnel, medical supplies and equipment. Although cruise lines remind us that this is not just a cruise issue, the incidence of illness caused by norovirus has increased significantly and ships traveling in warmer waters are especially at risk since outbreaks often occur in closed or semi closed communities. The cruise industry works with the Center for Disease Control and Prevention Vessel Sanitation Program designed for developing and implementing sanitation programs to minimize the risk for gastroenteritis, also addressed under the ShipSan Project. In the United Sates, the Cruise Vessel Security and Safety Act of 2010 requires a doctor or nurse to be onboard for the treatment of a victim sexual assault. While well intended, there are shortfalls in enforcement, financing and prosecution (Doherty, 2012). The Standard for Training Certification and Watch Keeping for Seafarers is the only international maritime law establishing some requirements (Klein, 2012).

In relation to safety and security, there are many regulatory and legal standards that apply to onboard safety and security which include flag state and port state laws. SOLAS is considered the most important of all international treaties concerning the safety of ships, which was amended in 2002 by the International Ship and Port Facility Security (IMO, 2002). It also includes the Standards of Training Certification and Watch Keeping and the International Safety Management rules. Security is not only related to 
the prevention of accidents and response systems, but also to criminality. Most common are sexual assaults and thefts which are in many cases related to alcohol use (Klein, 2012). The Manila Amendments (ISF/ICS, 2011) address alcohol consumption and cruise lines should implement an alcohol program that manages how alcohol is served to passengers.

In addition, there are specifically economic impacts of cruising included in the index. The cruise industry boasts of its positive economic impacts by creating jobs and contributing to the economy of destinations visited (ECC, 2011; Klein, 2011) but there is limited public data to substantiate this claim. In fact, low spend cruisers are considered unproductive given the costs incurred by the destination (Jayawardena, 2002; Larsen, Wolff, Marnburg, \& Øgaard, 2013). The duration of the visit and the number of spending opportunities correlates with the popularity and attractiveness of the destination (PRC, 2009), but these are too short and only allow passengers to take shore tours and do some shopping with very little time to interact with destinations, many of which are directly controlled by the cruise company itself. Many tourists simply stay on board, and those disembarking are encouraged to pay for excursions while on the ship (PRC, 2009) and are charged rates that include considerable commissions (Cuéllar Río \& Kido Cruz, 2008), reportedly 60 to 100\% in an additional margin (Johnson, 2006).

Earnings from the supply chain are limited. The requirements of cruise supply chains are complex. There is limited time to resupply, increasingly for larger numbers of passengers, and the need to forecast supply needs to ensure that ships do not run out of supplies despite having limited space for stock. These challenges are compounded by the added complexity of having mobile supply points due to the seasonal nature of the industry. This has resulted in a high concentration of suppliers via a single distribution point for product consistency, food safety and quality control with limited opportunities for local supply of produce, and therefore earnings (Lois, Wang, Wall, \&

Ruxton, 2004; Véronneau \& Roy, 2009).

Cruises differ from other large scale tourism operations in that they have the ability to take their business away to another destination, giving them more negotiating power for concessions, fees, and permits for docking. Destinations therefore have limited say in whether, when and how cruise ships visit (Manning, 2006). The cruise industry presents this resilience to economic downturns and geo-political events as a strength (ECC, 2011). When some Caribbean countries have tried to introduce an environmental levy to compensate for impacts, they have faced threats and often end up granting further concessions (Atherley, 2003). Obviously, there is a complex infrastructure of power relations, as Caribbean islands depend on tourism, and this results in high competition amongst destinations (Lester \& Weeden, 2004).

\section{Method}

A review of the literature helped in the development of a corporate social reporting index as a reliable proxy for a firm's corporate social reporting. The Global Reporting 
Initiative (GRI) sustainability reporting guidelines were developed as a way of helping organizations to report on their environmental, social and economic performance increasing their accountability, through the implementation of the transparency, inclusiveness, auditability, completeness, relevance, sustainability context, accuracy, neutrality, comparability, clarity and timeliness principles. Although environmental, social and economic impacts trade-offs are not possible, and it is not realistic to compensate with a company's environmental performance for the lack of social or economic performance; triple bottom line reporting is a necessary precondition for change. It can force organizations to measure and communicate more accurately than with only traditional financial reporting. Although the GRI has received criticism (Fonseca, McAllister, \& Fitzpatrick, 2012; Moneva, Archel, \& Correa, 2006), it is still the most relevant index and widely used in academic analyses (Morhardt, 2010).

GRI helped classify the aspects into environmental and socio-economic, and provided most of the indicators, unlike other studies that only focus on environmental aspects (Clarkson, Li, Richardson, \& Vasvari, 2008; Ramus \& Montiel, 2005). This study differs by focusing on a single industry, adding specific cruise sector indicators extracted from Global Sustainable Tourism Criteria; the GRI tour operators supplement; the International Convention for the Prevention of Pollution from ships (MARPOL); international legislative proposals like the Maritime Labour Convention (International Labour Conference, 2006) and specialized cruise industry literature as outlined earlier in this article.

Early studies suggest that the collection of process or management data is usually easier both for the company to gather and for stakeholders to understand, while outcome data collection is complex and more open to interpretation (llinitch, Soderstrom, \& Thomas, 1999). However the literature has evolved placing more demand on tangible data in two ways applied here. First, this study classifies the indicators into soft and hard to test mimetic behavior. "Hard categories", include information items related to objective data and measures "that cannot easily be mimicked by poor environmental performers" and "soft categories" that include information items related to claims that are not easily verifiable ( $\underline{\text { Clarkson et al., }}$ 2008:309). This is similar to de Grosbois' attempt to compare initiatives against performance measurements for the hotel industry (2012). Second, this study classifies the indicators into management and performance to test the level of maturity of their 
reporting systems. Management (or leading) indicators provide information on the organization's capabilities and efforts in managing matters such as training, legal requirements, resource allocation and documentation (Olsthoorn, Tyteca, Wehrmeyer, \& Wagner, 2001). Management efforts are a means to an end- that is, to influence an organization's performance. They often precede the disclosure or improvement of performance indicators (lagging indicators), which include specific actions related to procurement, production process and disposal as well as outputs such as emissions and water consumption (Kaplan \& Norton, 1996; Kolk \& Mauser, 2002).

Items classification

An annex downloadable from the journal's website provides the full set of indicators used in the CSR index, classified as soft/hard and management/performance, to encourage usage by other academics. The disclosure index consists of seven environmental categories ( $A 1$ to $A 7$ ), six social categories (B1 to $B 6$ ) and one economic category (C1).

Categories $\mathrm{A} 1$ and $\mathrm{B} 1$ focus on hard management disclosures related to a firm's governance structure and management systems put in place with respect to environmental protection and social responsibility (Jose, 2007). A1 scores the existence of an environmental or pollution prevention department and B1 scores the existence of a social responsibility department assessing issues such as human rights, occupational health and safety, product safety and impacts on destinations respectively. A2 and B2 focus on credibility, covering issues such as external awards and certification in environmental or social management systems (ISO 14001, SA 8000).

Environmental performance indicators are included in the A3 heading while B3 covers management and performance indicators related key social aspects such as labor and decent work, human rights, society, and product responsibility which include most relevant safety and security issues. A4 and B4 report on financial indicators arising from more proactive environmental initiatives, R\&D spending, fines and employee education. All of these items are easily verifiable and difficult for poor performers to mimic (Clarkson et al., 2008).

However, headings A5 to A7 and B5 to B6 are all considered soft items and include statements about a firm's environmental and social policy, strategy, codes of conduct, 
commitment to comply with current and future legislation, etc. Some consist of parts of environmental or social management systems which are not always integrated into the whole strategy of a company (Bonilla-Priego et al, 2011) and are the easiest practices to mimic.

Heading $\mathrm{C} 1$ is dedicated to economic indicators encompassing generic economic performance category, and economic impact on destinations. All seven indicators are labelled as hard, following the previous reasoning, since they refer to economic data easily verifiable and difficult to mimic, or specific measures implemented in destinations.

Sample

The population consisted of 80 cruise companies in the membership data of the principal cruise line associations as of October 2011 [Cruise Lines International Association (CLIA) and Florida-Caribbean Cruise Association (FCCA) in USA and Canada, European Cruise Council (ECC) in Europe and finally International Cruise Council Australasia (ICCA) and Japan Oceangoing Passenger Ship Association (JOPA) in Asia]. Within the sample of 80 cruise companies we searched for any CSR information in company reports, internet websites or other public documents. Three companies were dropped as all the information was in Japanese or German. 30 provided some sustainability or environmental responsibility information, but NYK Group was dropped since it is made up of logistics firms with just three cruise ships out of 827 vessels. Our "sampling unit" is therefore data from 29 cruise companies in Autumn 2011, consisting of sustainability reports, website information and additional reports available as redirects from the company's main website (for example, Carbon Disclosure reports). The date is important because several companies were reporting for the first time, but afterwards they reported as a group and not independently, hence it provides useful baseline data. Table 1 shows the 11 companies that had CSR reports (from now on, Group 1) and table 2 shows the 18 companies that only had information on their website (Group 2). Group 3 is the 51 cruise companies that did not report any aspect of sustainability, which is worth bearing in mind but will not be the focus of this study. 
Table 1. Company characteristics and CSR reporting practices (Group 1- CSR reports and website content)

\begin{tabular}{|c|c|c|c|c|c|c|c|c|c|}
\hline 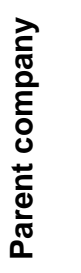 & & & 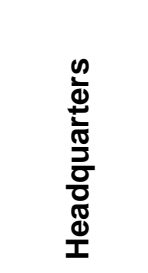 & 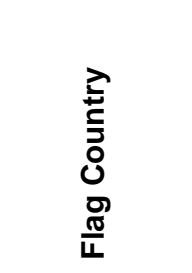 & 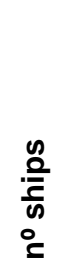 & 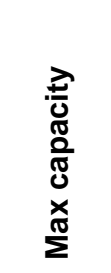 & 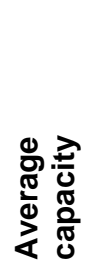 & 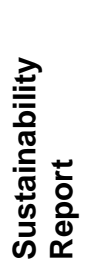 & 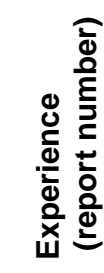 \\
\hline \multirow{9}{*}{ 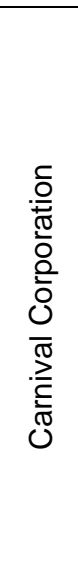 } & \multicolumn{2}{|c|}{ Princess Cruises } & US & Bermuda & 17 & 45506 & 2677 & 2009 & $1^{\text {st }}$ \\
\hline & \multicolumn{2}{|c|}{ Holland America Line } & US & Netherlands & 15 & 30292 & 2019 & 2009 & $1^{\text {st }}$ \\
\hline & \multicolumn{2}{|c|}{ Costa Cruises } & Italy & Italy & 14 & 37118 & 2651 & 2010 & $6^{\text {th }}$ \\
\hline & \multicolumn{2}{|c|}{ P\&O Australia } & Australia & Liberia & 4 & 7500 & 1875 & 2010 & $2^{\text {nd }}$ \\
\hline & \multicolumn{2}{|c|}{ Carnival Cruise Lines } & US & Panama & 23 & 74007 & 3218 & 2009 & $1^{\text {st }}$ \\
\hline & \multicolumn{2}{|c|}{ AIDA } & Germany & Italy & 8 & 14210 & 1776 & 2011 & $3^{\text {rd }}$ \\
\hline & \multicolumn{2}{|c|}{ Yachts of Seabourn } & US & Bahamas & 4 & 1074 & 268 & 2009 & $1^{\text {st }}$ \\
\hline & \multirow[b]{2}{*}{$\begin{array}{l}\text { Carnival } \\
\text { UK }\end{array}$} & $\begin{array}{l}\text { Cunard } \\
\text { UK }\end{array}$ & UK & Bermuda & 3 & 6960 & 2320 & \multirow[b]{2}{*}{2010} & \multirow[b]{2}{*}{$2^{\text {nd }}$} \\
\hline & & P\&O UK & UK & Bermuda & 7 & 16678 & 2383 & & \\
\hline & \multicolumn{2}{|c|}{ TUI Travel } & UK & Malta & 5 & 7020 & 1404 & 2010 & $3^{\text {rd }}$ \\
\hline \multirow{4}{*}{$\begin{array}{l}\bar{\Upsilon} \\
\check{Q}\end{array}$} & \multicolumn{2}{|c|}{ Royal Caribbean } & US & Bahamas & 22 & 72074 & 3276 & \multirow{3}{*}{2010} & \multirow{3}{*}{$3^{\text {rd }}$} \\
\hline & \multicolumn{2}{|c|}{ Celebrity Cruises } & US & Malta & 11 & 27166 & 2470 & & \\
\hline & \multicolumn{2}{|c|}{ Azamara } & US & Malta & 2 & 1388 & 694 & & \\
\hline & \multicolumn{2}{|c|}{ Disney Cruise Line } & US & Bahamas & 4 & 12800 & 3200 & 2010 & $3^{\text {rd }}$ \\
\hline
\end{tabular}

Source: authors 
Table 2. Company characteristics and CSR reporting practices (Group 2- website content only)

\begin{tabular}{|c|c|c|c|c|c|}
\hline 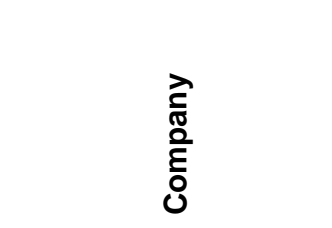 & 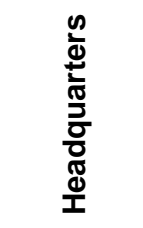 & 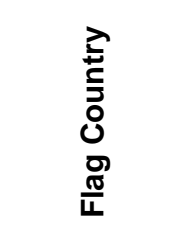 & 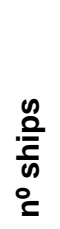 & 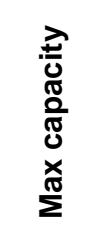 & 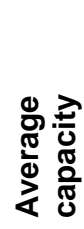 \\
\hline Crystal Cruises & US & Bahamas & 2 & 1992 & 996 \\
\hline Norwegian CL & US & $\begin{array}{c}\text { Bahamas/ } \\
\text { USA }\end{array}$ & 12 & 29632 & 2469 \\
\hline Hapa Lloyd & Germany & Bahamas & 5 & 1970 & 394 \\
\hline Genting HK & China & $\begin{array}{c}\text { Bahamas/ } \\
\text { Panama }\end{array}$ & 5 & 7238 & 1448 \\
\hline MSC Cruises & US & Panama & 12 & 31840 & 2653 \\
\hline Orion & Australia & Bahamas & 1 & 106 & 106 \\
\hline SilverSea & Monaco & Bahamas & 6 & 2028 & 338 \\
\hline Windstar & US & Bahamas & 3 & 606 & 202 \\
\hline Uniworld & US & Netherlands & 17 & 2069 & 122 \\
\hline Fred Olsen & Norway & Bahamas & 4 & 3963 & 991 \\
\hline Tauck & US & Switzerland & 4 & 472 & 118 \\
\hline Avalon & $\begin{array}{l}\text { Switzerla } \\
\text { nd }\end{array}$ & Germany & 19 & 2822 & 148 \\
\hline Scenic tour & Australia & Malta & 6 & 957 & 159 \\
\hline Compagnie du Ponant & France & France & 4 & 856 & 214 \\
\hline Iberocruceros & Spain & Portugal & 3 & 5104 & 1701 \\
\hline Lüftner & Austria & Germany & 11 & 1656 & 151 \\
\hline Paul Gauguin & & Bahamas & 1 & 332 & 332 \\
\hline Hurtigruten & Norway & Norway & 12 & 7721 & 643 \\
\hline
\end{tabular}

\section{Data analysis}

Content analysis is used in this article to analyze corporate sustainability reporting practices of cruise companies as is considered the dominant research method for collecting empirical evidence in the field of social and environmental accounting and reporting (Guthrie \& Abeysekera, 2006; Parker, 2005; Silverman, 2009; Steenkamp, 2007). We developed a coding sheet and a set of rules for coding texts. The information published by companies was codified according to the following rules. If the information found in publications of a specific company is relative to one of the items included in a specific category, we assign "1" to that item. If information related to a 
specific item was not found in specific company publications, we assigned " 0 " to that item- we reiterate that as this is a disclosure index, we did not set out to test whether the information provided shows a high level of performance, simply if the company publicly acknowledges what they are doing in respect to each issue. We did not analyze the level of performance, weigh the importance or intensity of indicators (Abbott \& Monsen, 1979; Font, Walmsley, Cogotti, McCombes, \& Häusler, 2012; Wiseman, 1982), although the instrument was originally designed to capture data intensity as well as availability, following Clarkson et al (2008), because the available reported data did not make this possible.

Actions were taken to assure validity and reliability (Milne \& Adler, 1999; Morhardt, 2010). Semantic validity was assured by means of precise operative definitions of every one of the analytic categories and items that we analyzed. A large part of these categories has a generally accepted definition supplied by GRI and international organizations linked to tourism and maritime navigation. Categories without previous definition were set by us based on existing literature. Structural validity was assured by a detailed description of the steps followed, decision making rules, and process of making inferences, outlined in the results when necessary. In terms of reliability, we could not measure accuracy as there are no CSR reference units in the cruise sector recognized as optimal or appropriate to benchmark against. However, coding consistency was achieved by two researchers independently coding reports using the same recording instructions to the same units of analysis.

\section{Results}

We analyze the level (how much information is provided), verifiability (hard/soft data) and breadth of disclosure (range of aspects addressed in the reports). We also consider the impact of reporting disclosure against reporting experience and company characteristics. Table 3 presents the results of the cruising corporate sustainability reporting index, presenting average and individual results for Group 1 and Group 2 companies. 
Table 3. CSR disclosure (in \% from total of indicators per category and aspect). (Group 1- CSR reports and website content)

\begin{tabular}{|c|c|c|c|c|c|c|c|c|c|c|c|c|c|c|}
\hline Category (number of indicators) & 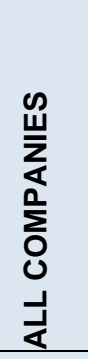 & $\begin{array}{l}-1 \\
0 \\
0 \\
0 \\
0 \\
0\end{array}$ & $\begin{array}{l}N \\
0 \\
\frac{N}{0} \\
0 \\
0 \\
0\end{array}$ & 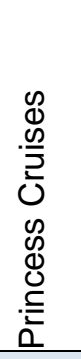 & 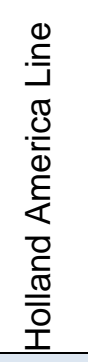 & 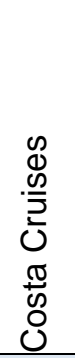 & 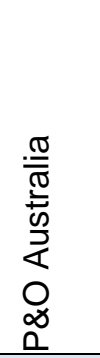 & 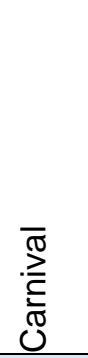 & 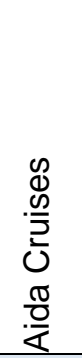 & 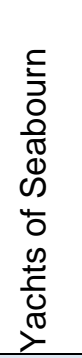 & 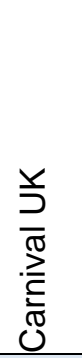 & 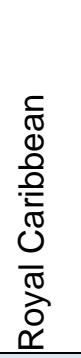 & 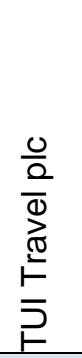 & 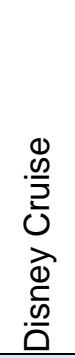 \\
\hline TOTAL & 16 & 39 & 3 & 53 & 52 & 48 & 46 & 45 & 40 & 38 & 32 & 26 & 26 & 22 \\
\hline ENVIRONMENT: TOTAL (84) & 18 & 42 & 3 & 50 & 50 & 54 & 50 & 50 & 46 & 38 & 32 & 32 & 32 & 27 \\
\hline $\begin{array}{ll}\text { (13) } & \text { SOFT DISCLOSURE } \\
\end{array}$ & 24 & 51 & 8 & 38 & 77 & 62 & 62 & 54 & 31 & 54 & 23 & 69 & 62 & 31 \\
\hline (71) HARD DISCLOSURE & 17 & 41 & 3 & 52 & 45 & 52 & 48 & 49 & 49 & 37 & 34 & 27 & 28 & 27 \\
\hline MANAGEMENT (37) & 20 & 43 & 6 & 38 & 54 & 54 & 38 & 46 & 30 & 35 & 32 & 49 & 62 & 41 \\
\hline PERFORMANCE (47) & 16 & 41 & 1 & 60 & 47 & 53 & 60 & 53 & 60 & 43 & 32 & 21 & 11 & 17 \\
\hline $\begin{array}{l}\text { A1 Governance structure and } \\
\text { management systems }\end{array}$ & 29 & 66 & 6 & 71 & 71 & 71 & 57 & 57 & 43 & 29 & 57 & 86 & 100 & 86 \\
\hline A2 Credibility & 19 & 35 & 9 & 30 & 30 & 70 & 10 & 50 & 30 & 30 & 30 & 20 & 70 & 50 \\
\hline $\begin{array}{l}\text { A3 Environmental Performance } \\
\text { Indicators }\end{array}$ & 16 & 41 & 1 & 60 & 47 & 53 & 60 & 53 & 60 & 43 & 32 & 21 & 11 & 17 \\
\hline Materials & 0 & 0 & 0 & 0 & 0 & 0 & 0 & 0 & 0 & 0 & 0 & 0 & 0 & 0 \\
\hline Water & 24 & 64 & 0 & 100 & 67 & 100 & 100 & 100 & 100 & 100 & 33 & 0 & 0 & 0 \\
\hline Biodiversity & 0 & $\mathbf{0}$ & 0 & 0 & 0 & 0 & 0 & 0 & 0 & 0 & 0 & 0 & 0 & 0 \\
\hline $\begin{array}{l}\text { Emissions, effluents and } \\
\text { waste }\end{array}$ & 19 & 48 & 1 & 69 & 54 & 60 & 69 & 60 & 69 & 46 & 40 & 26 & 11 & 20 \\
\hline Products and services & 21 & 45 & 6 & 50 & 50 & 50 & 50 & 50 & 50 & 50 & 0 & 50 & 50 & 50 \\
\hline A4 Environmental financial indicators & 5 & 14 & 0 & 14 & 29 & 0 & 14 & 14 & 14 & 14 & 29 & 14 & 14 & 0 \\
\hline A5 Vision and strategy claims & 35 & 68 & 15 & 33 & 83 & 100 & 83 & 67 & 50 & 83 & 17 & 100 & 83 & 50 \\
\hline A6 Environmental Profile & 16 & 39 & 2 & 33 & 67 & 0 & 67 & 33 & 0 & 33 & 67 & 67 & 33 & 33 \\
\hline A7 Environmental Initiatives & 14 & 34 & 1 & 50 & 75 & 50 & 25 & 50 & 25 & 25 & 0 & 25 & 50 & 0 \\
\hline
\end{tabular}




\begin{tabular}{|c|c|c|c|c|c|c|c|c|c|c|c|c|c|c|}
\hline Category (number of indicators) & 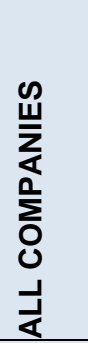 & $\begin{array}{l}-1 \\
0 \\
0 \\
0 \\
0 \\
0 \\
0\end{array}$ & 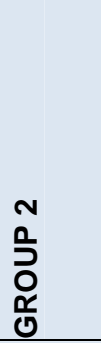 & 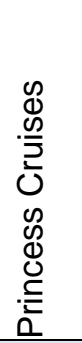 & 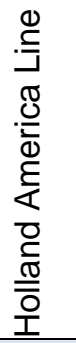 & 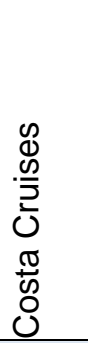 & 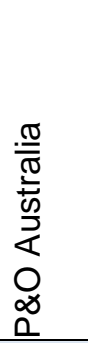 & 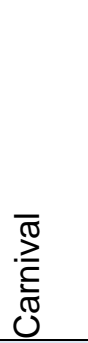 & 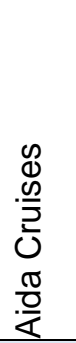 & 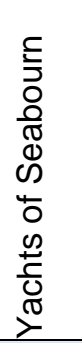 & 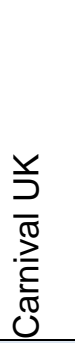 & 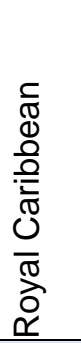 & 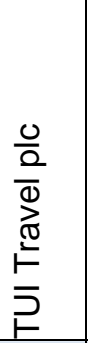 & 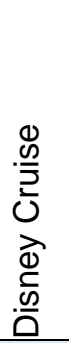 \\
\hline TOTAL & 16 & 39 & 3 & 53 & 52 & 48 & 46 & 45 & 40 & 38 & 32 & 26 & 26 & 22 \\
\hline SOCIO-ECONOMIC: TOTAL (110) & 14 & 34 & 2 & 51 & 48 & 38 & 40 & 37 & 32 & 35 & 29 & 17 & 17 & 15 \\
\hline $\begin{array}{ll}(23) & \text { SOFT DISCLOSURE } \\
\end{array}$ & 13 & 31 & 3 & 52 & 39 & 30 & 52 & 26 & 22 & 35 & 9 & 26 & 22 & 26 \\
\hline $\begin{array}{ll}\text { (87) } & \text { HARD DISCLOSURE } \\
\end{array}$ & 14 & 34 & 1 & 53 & 53 & 43 & 37 & 40 & 34 & 36 & 37 & 15 & 17 & 14 \\
\hline MANAGEMENT (61) & 13 & 30 & 3 & 38 & 41 & 34 & 39 & 28 & 23 & 30 & 18 & 21 & 30 & 23 \\
\hline PERFORMANCE (49) & 15 & 38 & 0 & 72 & 61 & 47 & 41 & 49 & 43 & 43 & 47 & 12 & 4 & 8 \\
\hline $\begin{array}{l}\text { B1 Governance structure and } \\
\text { management systems }\end{array}$ & 16 & 39 & 1 & 33 & 33 & 67 & 17 & 33 & 33 & 33 & 17 & 33 & 67 & 67 \\
\hline B2 Credibility & 17 & 36 & 6 & 42 & 42 & 50 & 8 & 33 & 42 & 50 & 17 & 33 & 50 & 25 \\
\hline B3 Key Social Indicators & 13 & 33 & 1 & 58 & 55 & 35 & 41 & 41 & 32 & 34 & 39 & 13 & 7 & 8 \\
\hline Labour and decent work & 18 & 48 & 0 & 83 & 77 & 63 & 47 & 70 & 53 & 53 & 53 & 7 & 7 & 13 \\
\hline Human rights & 8 & 22 & 0 & 31 & 23 & 38 & 23 & 15 & 38 & 8 & 46 & 0 & 8 & 8 \\
\hline Society & 9 & 22 & 2 & 12 & 62 & 0 & 50 & 38 & 12 & 12 & 25 & 0 & 25 & 0 \\
\hline Product responsibility & 9 & 23 & 1 & 55 & 40 & 5 & 40 & 15 & 5 & 30 & 20 & 35 & 0 & 5 \\
\hline B4 Social spending & 0 & 0 & 0 & 0 & 0 & 0 & 0 & 0 & 0 & 0 & 0 & 0 & 0 & 0 \\
\hline B5 Vision and strategy claims & 31 & 68 & 8 & 83 & 83 & 100 & 83 & 83 & 67 & 83 & 17 & 50 & 50 & 50 \\
\hline B6 Social profile & 12 & 27 & 2 & 60 & 40 & 20 & 40 & 20 & 20 & 40 & 0 & 20 & 20 & 20 \\
\hline C1 Economic indicators & 6 & 16 & 1 & 22 & 22 & 22 & 67 & 0 & 0 & 0 & 22 & 0 & 11 & 11 \\
\hline Economic performance & 5 & 12 & 0 & 33 & 33 & 0 & 67 & 0 & 0 & 0 & 0 & 0 & 0 & 0 \\
\hline $\begin{array}{l}\text { Economic impact on } \\
\text { destinations }\end{array}$ & 7 & 18 & 1 & 17 & 17 & 33 & 67 & 0 & 0 & 0 & 33 & 0 & 17 & 17 \\
\hline
\end{tabular}

Source: authors 
Table 4. CSR disclosure (in \% from total of indicators per category). (Group 2- website content only)

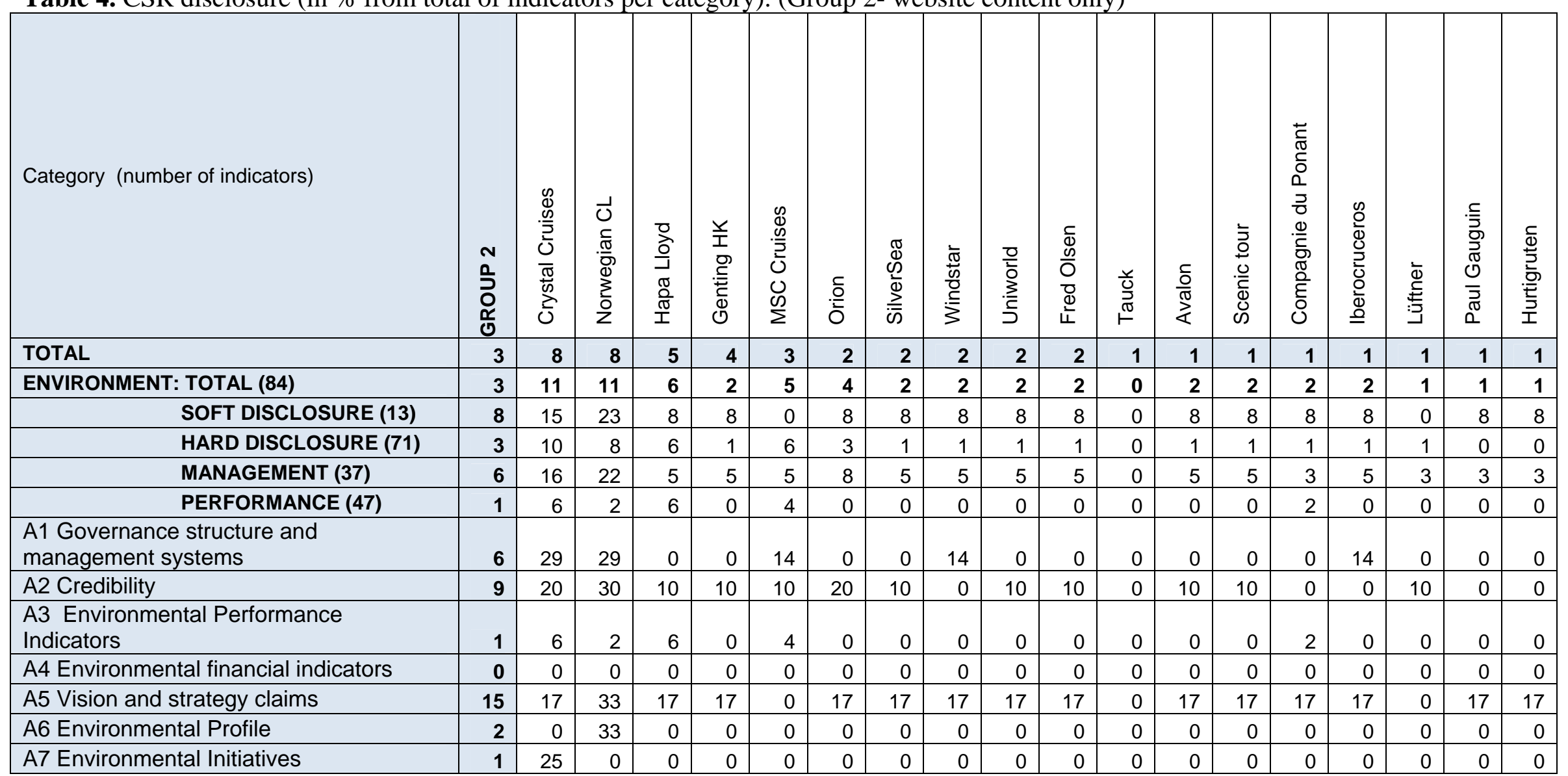




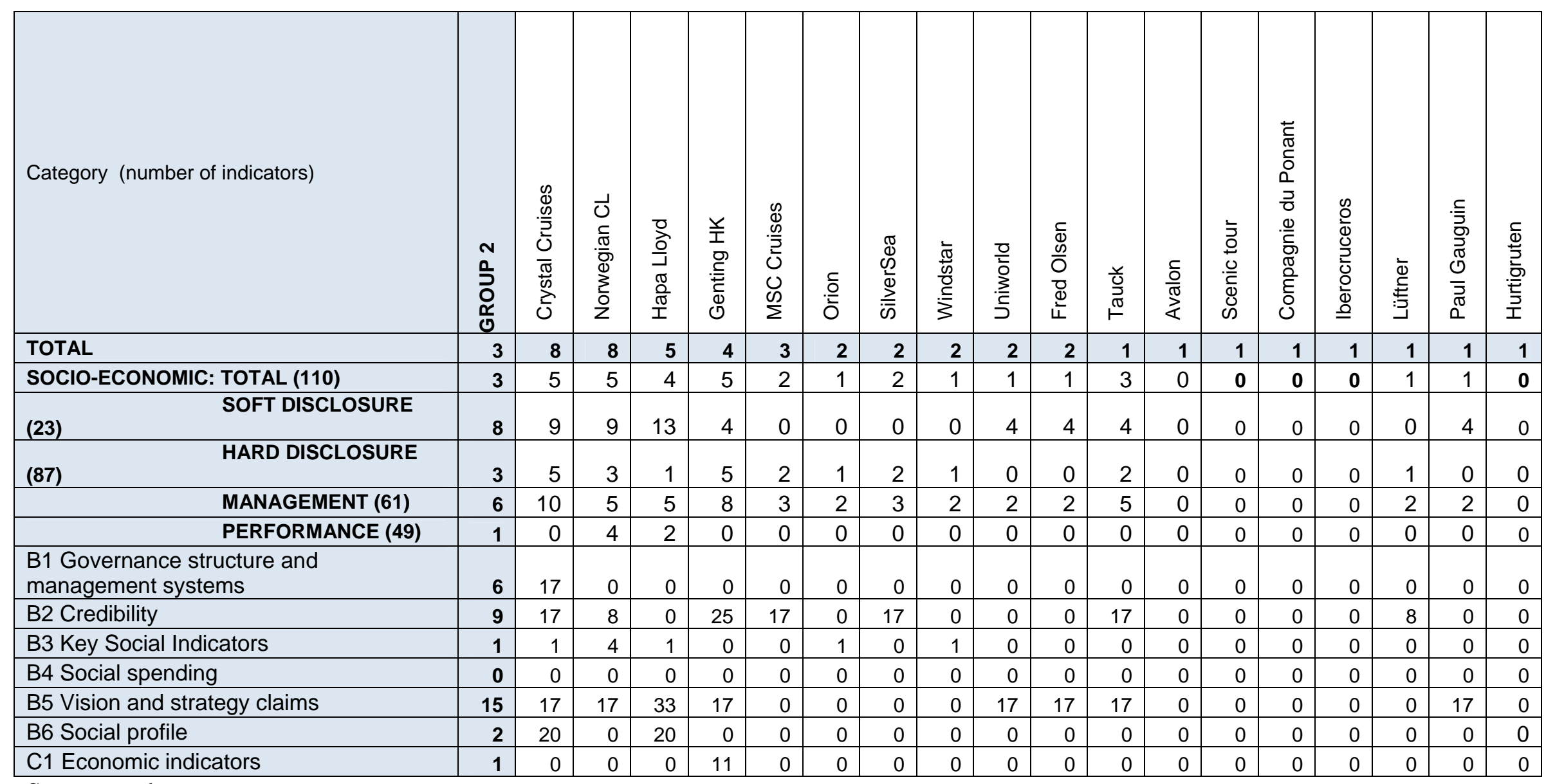

Source: authors 
Category A1 reaches the highest score as all companies have an environmental department, but just a few cases link executive compensation to environmental performance. Most have ISO 14001 certification and many apply environmental terms to suppliers and/or customers and make environmentally-related donations. However, credibility (category A2) has a considerably lower score, because although most companies claim to follow GRI reporting guidelines to report on sustainability and have received an environmental award, only the Costa report has GRI verification; few involve stakeholders in the disclosure process and only Tui and Disney are included in the FTSE4Good and Dow Jones sustainability indexes.

Category A3 is especially relevant since environmental performance is the result of the environmental practices adopted. No companies reported on the consumption of materials or biodiversity impacts. Instead most information is focused on energy consumption and emissions, although scores were low due to a failure to report complete information on emissions from indirect energy consumption or the methodology used. Many describe their use of advanced water treatment systems to explain waste-water discharge while few report on their ballast wastewater management practices- average scores are therefore low despite addressing some of the issues. TUI, Disney and Royal Caribbean provide no information on water discharge. The first two report on cruising as part of their global portfolio of activities, dedicating less space to sector specific aspects. In spite of reporting on emissions, there is limited information on efforts and technologies adopted such as fuel alternatives and shore-side power. Despite most companies reporting on solid waste generation, the average score is near $50 \%$ as scarce information is provided on ashes and safe hull coatings.

A4 is the last hard data category, devoted to monetary information related to environmental spending and environmental fines. The score comes mainly from information related to the number and the amount spent on sanctions. Categories A5 to A7 record soft environmental indicators. We record high scores in both as even companies without a sustainability report declare a commitment to protect the environment (A5 vision and strategy claims) and many describe future environmental goals (A7 environmental initiatives).

Governance structures and management systems score lower in the social than environmental dimensions (39\% to 66\%). A CSR department or similar organizational body is not widely found in cruise lines, especially in Group 2 companies. For those that do have them, few details about the recruiting system were provided, while the 
most reported aspects are those of employment and training. However, there is much less information about sensitive issues such as labor management relations and occupational, health and safety. With the exception of highly risky areas such as child compulsory labor, indicators included in other social dimension areas (human rights, society and product responsibility) show a low score. When looking at communities, the indicator related to describing policies on selecting destinations is the best rated indicator, but only the economic implications, like changing itineraries to reduce fuel consumption, are described. Although $63 \%$ disclose practices related to customer satisfaction and the results of surveys, few identify which flag they are sailing under and never indicate the reason and process for choosing a particular country.

The economic dimension is by far the least addressed. Reports rarely provide their own economic data, and far fewer discuss specific economic impacts in destinations and measures to improve local communities' economic development. The most reported indicator relates to creating infrastructure for community development. Cruise lines refer to providing equipment for educational, health or sanitation facilities- in effect charitable donations. And all too often they were providing infrastructure help only at their home ports, many in the United States, but not in their destinations communities.

\section{Discussion}

Cruising lacks the normative and cultural institutions to incentivize industry wide CSR (Campbell, 2007). The industry has not yet reached mimetic behavior (Ramus \& Montiel, 2005) and cruising is unusual in having few top scorers- industries with more CSR experience have a fairly linear decline in reporting scores (Morhardt, 2010). This suggests that with data from 2010, the cruise industry would not be ready to accept CSR industry self-regulation and would resist government intervention (Campbell, 2007). Group 1 reports on $38 \%$ of the indicators, showing that producing corporate sustainability reports significantly improves the level of disclosure (table 3). Group 2 seems to react to sector wide pressures by making weak public declarations of commitment ( $3 \%$ environment and $2 \%$ socio-economic indicators) (table 4 ). Yet the bulk of companies do not report (Group 3), similarly to what was found in the hospitality industry (de Grosbois, 2012).

We are at a stage of conservative social accounts reflecting the voice of the cruise companies, not their stakeholders. Tables 3 and 4 show a greater disclosure of environmental aspects that lead to cost savings and cost avoidance (water; emissions, effluents and waste; products and services) in line with "beyond compliance theory" 
(Reinhardt, 1999), suggesting that stakeholder influence is still limited at this stage. In the social dimension, regulation seems to be the main stakeholder as that is the basis for companies acting. But there is scarce information about how these businesses are getting ready to deal with sensitive issues forthcoming by regulation such as the management of recruitment agencies, hours of work and rest, confirmation of contractual conditions in writing, all addressed by the Maritime Labour Convention which only entered into force in 2013 , but with a low likelihood of being implemented in full (Piniella, et al., 2013). Meanwhile, Community and Economic indicators have the lowest scores of all in our study, and these are considerably lower than in other sectors with $45 \%$ claiming community involvement ( Jose \& Lee, 2007).

Both legitimacy and stakeholder theory would suggest that the groups least mentioned or addressed are those with the least power (Cormier, et al., 2004; Elijido-Ten, et al., 2010; Henriques \& Sadorsky, 1999; O Dwyer, 2002). Stakeholder theory will tell us about the responsibilities accepted by cruise companies, while accountability theory will focus on those moral rights to information needs not met due to power asymmetries (Gray, et al., 1997). Service sector employees did not believe that their companies were implementing sustainability practices as strongly as in other sectors (Ramus \& Montiel, 2005), and cruise companies involving staff, customers and suppliers in environmental management systems is much lower than average ( Lee, 2007). The results confirm that cruises are in a position of strength in dictating how destinations will cater to their needs (Lester \& Weeden, 2004), while destinations cannot contest cruises' self-reported legitimacy.

As a result of this limited stakeholder pressure, there is little commitment to changing practices that would affect the core of the business. For example sustainable supply chain management policies, which should impact on Materials or Biodiversity (A3 in tables 3 and 4), are absent from every company. Equally the choices of itineraries are justified in these CSR reports by fuel cost or in some cases security $(\mathrm{RCl})$ but not by destination impacts such as avoiding crowding, as no company scored on the indicator SO.2, and SO.3 scored up to $18 \%$. This is typical of other industries that downplay responsibility towards suppliers or through the supply chain and prefer to mention issues not affected by their activities (Maignan \& Ralston, 2002) as CSR policies tend to deal with the edges of business (Laufer, 2003; Ramus \& Montiel, 2005). Environmental policies that do not have an economic benefit are less likely to be applied (Ramus \& Montiel, 2005)- which is consistent with disclosure-performance gaps found in the hospitality sector (de Grosbois, 2012; Font, et al., 2012). 
We also find that company size is directly related to CSR disclosure for the cruise industry (see tables 1 and 2) as it is primarily brands within Carnival and Royal Caribbean that report. Disney Cruise Lines and Tui (through ThomsonCruise Lines) are small cruise operators, but belonging to corporations already reporting on CSR, and some of their scores are the result of company-wide practices that may not be specifically applied to their cruise sector. Surprisingly we still find large companies not reporting (Norwegian and MSC Cruises for example, see tables 2 and 4). Company size and environmental risk increase the level of reporting (Morhardt, 2010). With the environmental threat being similar for all cruise companies, company visibility and stakeholder pressures would explain the level of corporate commitment to reporting (Adams, et al., 1998). However, our research did not find that country where the company is headquartered impacts on CSR reporting (tables 1 and 2), as happens in other industries (Maignan \& Ralston, 2002). We attribute this to the globalized nature of these firms, applying laws from the countries where their ships are registered and not necessarily where the corporations are headquartered. Our data did not allow us to test if fixed assets age- how old cruise lines are- would influence CSR disclosure (Cormier, et al., 2005), although intuitively it is clear that newer ships are more efficient and lend themselves to good public relations, often to counteract the fact that they are considerably larger.

There is a clear relationship between the amount of disclosure and the aspects disclosed, as shown in Table 5. Companies disclosing less information (Group 2) are proportionally more likely to focus on soft and management indicators. Group 2 companies report on some credibility systems in place (A2, B2) and make general statements (A5, B5) before providing performance data. Graph 1 shows this behavior in relation to environmental soft/hard disclosure. The amount of hard indicators is higher for the companies that overall report more, although for Group 1 companies the soft indicators show a more volatile behavior consistent with the fact that are easier to mimic and less relevant for better performers who can also provide hard data. For Group 1 companies, the reasons for focusing on them can respond also to different types of reports and company structures. For example, Tui and Royal Caribbean may well report on more soft indicators because Tui is reporting for the whole group where cruising is of limited importance, while Royal Caribbean reports on the cruise activity of three cruise lines (RC, Celebrity and Azamara). This pattern was similar when comparing other ratios which for space reasons are not displayed in this article but can be calculated from Tables 3 and 4 . The behavior is consistent with the literature, showing that companies are likely to publish broad statements but not make specific 
commitments when they feel the need to legitimize their behavior (Adams et al., 1998; Clarkson et al, 2008). Ramus and Montiel (2005) show that service sector firms are just as likely to commit but less likely to implement environmental policies, evidenced also in the hospitality industry (de Grosbois, 2012).

Table 5. CSR disclosure ratios

\begin{tabular}{|c|c|c|}
\hline Ratios & $\begin{array}{l}-1 \\
0 \\
0 \\
0 \\
\frac{x}{0} \\
0\end{array}$ & 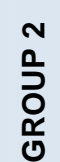 \\
\hline Environmental hard/soft & 0.8 & 0.4 \\
\hline $\begin{array}{l}\text { Environmental } \\
\text { performance/management }\end{array}$ & 0.9 & 0.2 \\
\hline Socio-economic hard/soft & 1.1 & 0.3 \\
\hline $\begin{array}{l}\text { Socio-economic } \\
\text { performance/management }\end{array}$ & 1.3 & 0 \\
\hline
\end{tabular}

Source: authors 


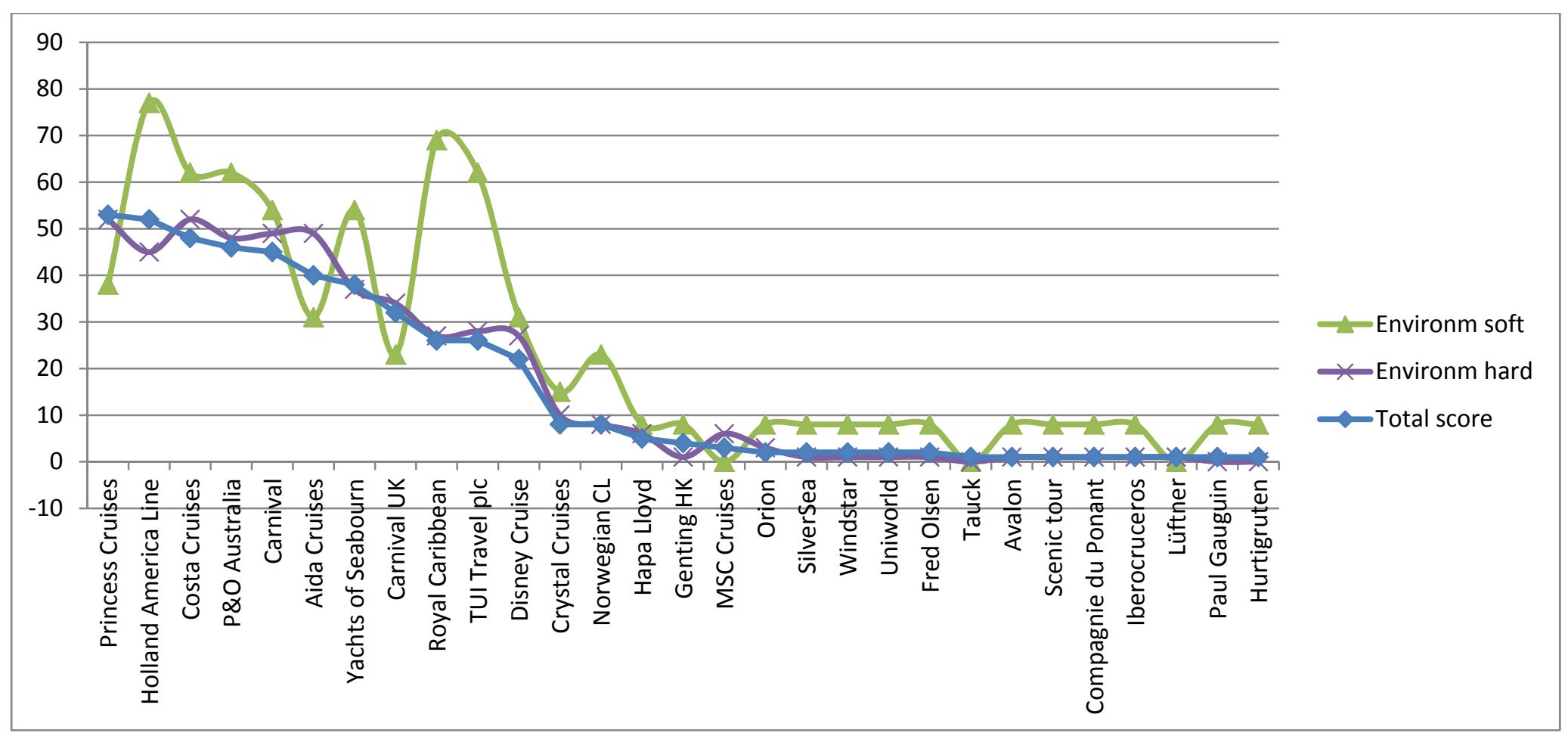

Source: authors 
In addition Table 5 also shows how companies disclosing less information (Group 2) disclose more management than performance data. If we apply Kolk and Mauser's (2002) argument that management indicators are leading and therefore visible in the organization earlier than the performance or lagging indicators, we would expect that in the early years of reporting we would have a higher proportion of the management indicators. Once companies report (Group 1) the difference is no longer evident- we find some cruise companies in their third report with a disproportionately higher percentage of soft and management indicators that fail to communicate what difference these make to performance, while several Carnival companies reporting for the first time have more hard and performance indicators (see tables 1 and 3).

Currently, experience in reporting does not impact on the level of CSR disclosure (see table 1). Costa reports on $47 \%$ of indicators and ranks third despite being the most experienced company and having the only report validated by GRI. Instead, three of the top five companies are reporting for the first time, and TUI, Royal Caribbean and Disney all report between $26 \%$ and $22 \%$ of indicators despite being in their third year of reporting. It is important to fully understand the period studied as it was the beginning of the cruise industry's acceptance of CSR reporting as standard practice as explained by institutional theory (DiMaggio \& Powell, 1983). Institutional isomorphism will influence group-think in the contents and style, both improving and standardizing reporting (Ramus \& Montiel, 2005). The subsequent 2010 Carnival Corporation Sustainability Report brings together data from all their companies, yet lacks detail on what each company does- longitudinal analysis is needed to further test how companies vary against our baseline data.

The current increase in sustainability reporting in cruising may be attributed to what Benoit called image restoration (1995), which will be expected to be triggered in part by the Costa Concordia accident and increasing legislation. The International Labour Organization's 2006 Maritime Labour Convention only came to force in August 2013, updating and unifying multiple international norms; as well as the Manila Amendments to the International Convention for the Safety of Life at Sea, which focus on training and rest hours requirements and which entered gradually into force in July 2012 (ISF/ICS, 2011). This may be an attempt towards changing perceptions but not behavior in an attempt of reputation risk management, or it may be a genuine attempt to take responsibility (Bebbington et al., 2008). A discourse analysis approach to the 
content may be able to complement quantitative measures in analyzing the more recent reports.

\section{Conclusions}

The contribution from this article resides in the creation of an index to measure CSR in the cruise industry, for which data was collected at a point in time significant to the evolution of the sector providing a basis for comparison. The voluntary nature and the lack of standardization of the content of these reports leads to a need to examine what circumstances make companies report different practices. This study contributes to the debate on how to measure and classify corporate disclosures by applying index indicators beyond the environmental disclosure where most theory has been developed. The classification as hard/soft and management/performance has provided an additional level of depth to the analysis to explain behavior.

The application to a specific sector helps further understand not only what is reported, but to suggest reasons for the practices reported. Already well-established in the corporate reporting literature, legitimisation theory has proven useful. The results suggest that the cruise industry is in the early stages of accepting responsibility. This is demonstrated by the small numbers of companies reporting dominated by the major international brands, while for the laggards there is an overall focus on soft indicators, the development of management systems with a limited disclosure of performance and the focus on indicators away from the core business practices. Recording sector specific baseline data will allow tracking progress in further stages.

This study only presents a first step in the development of a disclosure index. Improved company performance and a better understanding of the literature will eventually allow the grading of performance to create benchmarks, allowing the rating of practices according to the recording systems we had outlined in the methodology section, which had to be dropped as current cruise practices were too limited to create meaningful scales. In addition, further research on factors conditioning reporting should be undertaken to better understand the reporting process. Although the literature focuses on corporate characteristics, little research has examined internal factors such as the process of reporting and the attitudes of key players (Adams, 2002) which will go deeper in the stakeholder consultation process and governance structures. 


\section{References}

Abbott, W. F., \& Monsen, R. J. (1979). On the measurement of corporate social responsibility: Self-reported disclosures as a method of measuring corporate social involvement. Academy of Management Journal, 22, 501-515.

Adams, C., Hill, W. Y., \& Roberts, C. B. (1998). Corporate social reporting practices in Western Europe: legitimating corporate behaviour? British Accounting Review, 30, 1-22.

Adams, C.A. (2002). International organizational factors influencing corporate social and ethical reporting. Beyond current theorizing. Accounting, Auditing and Accountability Journal, $15,223-249$.

Adams, C.A. (2004). The ethical, social and environmental reporting-performance portaryal gap. Accounting, Auditing\& Accountability Journal, 17, 731-757

Adams, C. A. (2008). A commentary on: corporate social responsibility reporting and reputation risk management. Accounting, Auditing \& Accountability Journal, 21, 365-370.

Atherley, K.A. (2003). Cruise industry - Related challenges facing Caribbean destinations. Report prepared for Organization of American States. (CIDI/CIP/doc. 135.03).

Barney, J. (1991). Firm resources and sustained competitive advantage. Journal of Management, 17, 99-120.

Bauer, P. J. (2007). Maritime Labour Convention: An Adequate Guarantee of Seafarer Rights, or and Impediment to True Reforms. Chigago Journal of International Law, 8, 643-655.

Bebbington, J., Larrinaga, C., \& Moneva, J. M. (2008). Corporate social reporting and reputation risk management. Accounting, Auditing \& Accountability Journal, 21, 337-361.

Benoit, W. L. (1995). Sears' repair of its auto service image: Image restoration discourse in the corporate sector. Communication Studies, 46, 89-105.

Bonilla-Priego, M.J., Najera, J.J. and Font, X. (2011). Environmental management decision-making in certified hotels. Journal of Sustainable Tourism, 19, 361382.

Branco, M. C., \& Rodrigues, L. L. (2006). Corporate social responsibility and resourcebased perspectives. Journal of Business Ethics, 69, 111-132.

Bresson, G., \& Logossah, K. (2011). Crowding-out effects of cruise tourism on stayover tourism in the Caribbean: Non-parametric panel data evidence. Tourism Economics, 17, 127-158.

Brewster, L.; Mwansa, J. (2001). Integrating management of watersheds and coastal areas in small islands developing states of the Caribbean: The Barbados National Report. Prepared for the Caribbean Environmental Health Institute and United Nations Environment Programme.

Brida, J. G., \& Zapata, S. (2010). Cruise tourism: economic, socio-cultural and environmental impacts. International Journal of Leisure and Tourism Marketing, $1,205-226$. 
Campbell, J. (2007). Why would corporations behave in socially responsible ways? An institutional theory of corporate social responsibility. Academy of Management Review, 32, 946-967.

Carroll, A. B. (1979). A three-dimensional conceptual model of corporate performance. Academy of Management Review, 4, 497-505.

Clarkson, P. M., Li, Y., Richardson, G. D., \& Vasvari, F. P. (2008). Revisiting the relation between environmental performance and environmental disclosure: An empirical analysis. Accounting, Organizations and Society, 33, 303-327.

CLIA (2012). Cruise Industry Policies. http://www.cruising.org/regulatory/cruiseindustry-policies. Fort Lauderdale, FL: Cruise Lines International Association.

COM (2007). Communication from the Commission to the European Parliament, the Council, the European and Social Committee and the Committee of the Regions. An Integrated Maritime Policy for the European Union. (COM (2007) 575 final). Brussels: Commission of the European Communities.

Cormier, D., Gordon, I. M., \& Magnan, M. (2004). Corporate environmental disclosure: contrasting management's perceptions with reality. Journal of Business Ethics, 49, 143-165.

Cormier, D., Magnan, M., \& Van Velthoven, B. (2005). Environmental disclosure quality in large German companies: economic incentives, public pressures or institutional conditions? European Accounting Review, 14, 3-39.

Cuéllar Río, M., \& Kido Cruz, M. T. (2008). Perfil y análisis del gasto del crucerista: el caso de Bahías de Huatulco (México). Cuadernos de turismo, 47-78.

de Grosbois, D. (2012). Corporate social responsibility reporting by the global hotel industry: Commitment, initiatives and performance. International Journal of Hospitality Management, 31, 896-905.

Deegan, C. (2002). Introduction: The legitimising effect of social and environmental disclosures-a theoretical foundation. Accounting, Auditing \& Accountability Journal, 15, 282-311.

DiMaggio, P. J., \& Powell, W. W. (1983). The iron cage revisited: Institutional isomorphism and collective rationality in organizational fields. American sociological review, 48, 147-160.

Dimitrova, D. N., \& Blanpain, R. (2010). Seafarers' rights in the globalized maritime industry (Vol. 75): Kluwer Law International.

Doherty, W. H. (2012). Oversight of the Cruise Ship Industry: Are Current Regulations Sufficient to Protect Passengers \& the Environment. Testimony before the Senate Committee on Commerce, Science and Transportation. Russell Senate Office Building. Room 253. March.

http://www.commerce.senate.gov/public/?a=Files.Serve\&File id=46b676e148c3-4b3e-b44f-f0fc0830090a. Washington: U.S. Senate Committee on Commerce, Science and Transportation.

EC (2009). Tourist Facilities in ports. The environmental factor. Directorate General for Maritime Affairs and Fisheries. Brussels: European Commission.

EC (2011). European Manual for Hygiene Standards and Communicable Diseases Surveillance on Passengers Ships. EU SHIPSAN TRAINET project work package 5. Directorate General for Health and Consumers. Brussels: European Commission.

ECC (2011). European Cruise Council 2010/11 Report. http://www.europeancruisecouncil.com/content/ecc_report_2010_2011.pdf.

London: European Cruise Council. 
ECC (2012). European Cruise Council 2012/13 Report. http://www.europeancruisecouncil.com/content/ECC\%20Report\%20201213.pdf. London: European Cruise Council.

Elijido-Ten, E., Kloot, L., \& Clarkson, P. (2010). Extending the application of stakeholder influence strategies to environmental disclosures: An exploratory study from a developing country. Accounting, Auditing \& Accountability Journal, 23, 1032-1059.

Eng, L. L., \& Mak, Y. T. (2003). Corporate governance and voluntary disclosure. Journal of Accounting and Public Policy, 22, 325-345.

EMEC (2010). Green Ship Technology Book. Existing Technology by the marine Equipment Industry: A contribution to the Reduction of the Environmental Impact of Shipping. April. ( $2^{\text {nd }}$ ed.). Brussels: European Marine Equipment Council.

EPA (2004). An Ocean Blue Print for the $21^{\text {st }}$ Century. U.S. Commission on Ocean Policy. Final Report. Washington D.C.: Environmental Protection Agency.

EPA (2008). Cruise Ship Discharge Assessment Report (Assessment Report), published on December 29, 2008. Reference number EPA 842-R-07-005. Washington D.C.: Environmental Protection Agency.

Fonseca, A., McAllister, M. L., \& Fitzpatrick, P. (2012). Sustainability Reporting among Mining Corporations: A Constructive Critique of the GRI Approach. Journal of Cleaner Production. http://dx.doi.org/10.1016/j.jclepro.2012.11.050

Font, X., Tapper, R., Schwartz, K., \& Kornilaki, M. (2008). Sustainable supply chain management in tourism. Business strategy and the environment, 17, 260-271.

Font, X., Walmsley, A., Cogotti, S., McCombes, L., \& Häusler, N. (2012). Corporate social responsibility: The disclosure-performance gap. Tourism Management, 33, 1544-1553.

Garay, L., \& Font, X. (2012). Doing good to do well? Corporate Social Responsibility Reasons, Practices and Impacts in Small and Medium Accommodation Enterprises. International Journal of Hospitality Management, 31, 328-336.

Gard AS (2011). Marpol Annex I. Regulation from the prevention of pollution by oil. A selection of articles previously published by Gard AS. June. Oslo: Gard AS.

Gollasch, S., Lenz, J., Dammer, M., \& Andres, H.-G. (2000). Survival of tropical ballast water organisms during a cruise from the Indian Ocean to the North Sea. Journal of Plankton Research, 22, 923-937.

Goodwin, H. (2011). Taking responsibility for tourism. Oxford: Goodfellow Publishers.

Gray, R., Colin, D., Owen, D., Evans, R., \& Zadek, S. (1997). Struggling with the praxis of social accounting: stakeholders, accountability, audits and procedures. Accounting Auditing and Accountability Journal, 10, 325-364.

Guthrie, J., \& Abeysekera, I. (2006). Content analysis of social, environmental reporting: what is new? Journal of Human Resource Costing \& Accounting, 10, 114-126.

Hadjichristodoulou, C., Mouchtouri, V. A., Martinez, C. V., Nichols, G., Riemer, T., Rabinina, J., Swan, C., Pirnat, N., Sokolova, O., \& Kostara, E. (2011). Surveillance and control of communicable diseases related to passenger ships in Europe. International Maritime Health, 62, 138-147.

Healy, P. M., \& Palepu, K. G. (2001). Information asymmetry, corporate disclosure, and the capital markets: A review of the empirical disclosure literature. Journal of Accounting and Economics, 31, 405-440.

Henriques, I. Y., \& Sadorsky, P. (1999). The Relationship between Environmental Commitment and Managerial Perceptions of Stakeholder Importance. Academy of Management Journal, 42, 87-99. 
Hooghiemstra, R. (2000). Corporate Communication and Impression Management New Perspectives Why Companies Engage in Corporate Social Reporting. Journal of Business Ethics, 27, 55-68.

ICCA (2012). Cruise Industry Report. Australia 2011. http://www.cruising.org.au/filelibrary/files/Australian\%20Cruise\%20Industry\%20 Printed\%20Report\%20lo-res.pdf. Belrose: International Cruise Council Australasia.

Ilinitch, A. Y., Soderstrom, N. S., \& E Thomas, T. (1999). Measuring corporate environmental performance. Journal of Accounting and Public Policy, 17, 383408.

IMO (2011). Status of Conventions Summary (31/10/2011) http://www.imo.org/About/Conventions/StatusOfConventions/Pages/Default.asp $\underline{X}$ London: International Maritime Organization.

IMO (2002). Amendments to the annex to the International Convention for the Safety of Life at Sea (SOLAS), 1974. Contained in Resolutions 1, 2, 6 and 7 and including International Ship and Port Facility Security (ISPS) Code. London: International Maritime Organization.

International Labour Conference. (2006). Maritime Labour Convention http://www.ilo.org/wcmsp5/groups/public/---ed norm/--normes/documents/normativeinstrument/wcms 090250.pdf In.

ISF/ICS (2011). Manila Amendments to the STCW Convention. A Quick guide for Seafarers. London: International Shipping Federation and International Chamber of Shipping

IUCN. (2008). Biodiversity: my hotel in action. A guide to sustainable use of biological resources. In. Gland: International Union for Conservation of Nature.

Jayawardena, C. (2002). Mastering Caribbean tourism. International Journal of Contemporary Hospitality Management, 14, 88-93.

Johnson, D. (2006). Providing ecotourism excursions for cruise passengers. Journal of Sustainable Tourism, 14, 43-54.

Jose, A., \& Lee, S.-M. (2007). Environmental reporting of global corporations: a content analysis based on website disclosures. Journal of Business Ethics, 72, 307321.

Kaplan, R. S., \& Norton, D. P. (1996). Using the balanced scorecard as a strategic management system. Harvard Business Review, 74, 75-85.

Kaptein, M. and Wempe, J. (1998) Twelve Gordian knots when developing an organizational code of ethics. Journal of Business Ethics, 17, 853-869.

Kaptein, M. (2007). Ethical guidelines for compiling corporate social reports. Journal of Corporate Citizenship, 27, 71-90.

Klein, R. A. (2003). Cruising--Out of Control: The Cruise Industry, The Environment, Workers, and the Maritimes: Canadian Centre for Policy Alternatives--Nova Scotia.

Klein, R. A. (2011). Responsible Cruise Tourism: Issues of Cruise Tourism and Sustainability. Journal of Hospitality and Tourism Management, 18, 107-116.

Klein, R. A. (2012). Hearings on "Oversight of the Cruise Industry". Testimony before the Senate Committee on Commerce, Science and Transportation. Russell $\begin{array}{llll}\text { Senate } & \text { Office } & \text { Building. } & \end{array}$ http://www.internationalcruisevictims.org/Senate2012.pdf. In.

Kolk, A., \& Mauser, A. (2002). The evolution of environmental management: from stage models to performance evaluation. Business strategy and the environment, 11, 14-31. 
Krippendorff, K. (1980). Content analysis: An introduction to its methodology. London: Sage Publications.

Larsen, S., Wolff, K., Marnburg, E., \& Øgaard, T. (2013). Belly full, purse closed: Cruise line passengers' expenditures. Tourism Management Perspectives, 6, 142-148.

Laufer, W. S. (2003). Social Accountability and Corporate Greenwashing. Journal of Business Ethics, 43, 253-261.

Lester, J. A., \& Weeden, C. (2004). Stakeholders, the natural environment and the future of Caribbean cruise tourism. International Journal of Tourism Research, 6, 39-50.

Lillie, N. (2005). Union Networks and Global Unionism in Maritime Shipping. Relations Industrielles/Industrial Relations, 60, 88-111.

Lois, P., Wang, J., Wall, A., \& Ruxton, T. (2004). Formal safety assessment of cruise ships. Tourism Management, 25, 93-109.

Maignan, I., \& Ralston, D. A. (2002). Corporate social responsibility in Europe and the US: Insights from businesses self-presentations. Journal of International Business Studies, 33, 497-514.

Manning, T. (2006). Managing Cruise Ship Impacts: Guidelines for Current and Potential Destination Communities. A Backgrounder for Prospective Destination Communities. http://www.tourisk.org/content/projects/Managing\%20Cruise\%20Ship\%20Impac ts.pdf Ottawa: Tourisk, Inc.

Milne, M. J., \& Adler, R. W. (1999). Exploring the reliability of social and environmental disclosures content analysis. Accounting, Auditing \& Accountability Journal, 12, 237-256.

Moneva, J. M., Archel, P., \& Correa, C. (2006). GRI and the camouflaging of corporate unsustainability. Accounting Forum, 30, 121-137.

Morhardt, J. E. (2010). Corporate social responsibility and sustainability reporting on the Internet. Business strategy and the environment, 19, 436-452.

O'Dwyer, B. (2002). Managerial perceptions of corporate social disclosure: an Irish story. Accounting, Auditing \& Accountability Journal, 15, 406-436.

O'Dwyer, B. (2003). Conceptions of corporate social responsibility: the nature of managerial capture. Accounting, Auditing \& Accountability Journal, 16, 523557.

Olsthoorn, X., Tyteca, D., Wehrmeyer, W., \& Wagner, M. (2001). Environmental indicators for business: a review of the literature and standardisation methods. Journal of Cleaner Production, 9, 453-463.

Parker, L. D. (2005). Social and environmental accountability research: a view from the commentary box. Accounting, Auditing \& Accountability Journal, 18, 842-860.

Piniella, F., Silos, J. M., \& Bernal, F. (2013). Who will give effect to the ILO's Maritime Labour Convention, 2006? International Labour Review, 152, 59-83.

PRC (2009). Tourists facilities in ports. The economic factor. Carried out on behalf of the European Commission Directorate-General for Maritime Affairs and Fisheries. Brussels: Policy Research Corporation

Ramus, C. A., \& Montiel, I. (2005). When Are Corporate Environmental Policies a Form of Greenwashing? Business Society, 44, 377-414.

Reinhardt, F. (1999). Market failure and the environmental policies of firms: Economic rationales for "beyond compliance" behavior. Journal of Industrial Ecology, 3, 921.

Seidl, A., Guiliano, F., \& Pratt, L. (2007). Cruising for colones: cruise tourism economics in Costa Rica. Tourism Economics, 13, 67-85. 
Silverman, H. I. (2009). Qualitative Analysis In Financial Studies: Employing Ethnographic Content Analysis. Journal of Business \& Economics Research (JBER), 7, 133-136.

Steenkamp, N. (2007). Intellectual Capital Reporting in New Zealand: Refining content analysis as a research method. Auckland University of Technology, Auckland, New Zeland.

Terry, W. C. (2009). Working on the water: On legal space and seafarer protection in the cruise industry. Economic Geography, 85, 463-482.

Véronneau, S., \& Roy, J. (2009). Global service supply chains: An empirical study of current practices and challenges of a cruise line corporation. Tourism Management, 30, 128-139.

Williams, R., Griffiths, F., Van der Wal, E., \& Kelly, J. (1988). Cargo vessel ballast water as a vector for the transport of non-indigenous marine species. Estuarine, Coastal and Shelf Science, 26, 409-420.

Wiseman, J. (1982). An evaluation of environmental disclosures made in corporate annual reports. Accounting, Organizations and Society, 7, 53-63. 